Short Communication

\title{
Corrosion Investigation of Reinforced Concrete Under Qinghai Salt Lake Environment By EIS
}

Qing Liu ${ }^{1, *}$, Bokun Chen ${ }^{l}$ and Ying $\mathrm{Li}^{1}$

School of Civil Engineering, Qinghai University, Qinghai 810016, P.R . China.

*E-mail: bokunchen_qinhai@yahoo.com

doi: $10.20964 / 2016.12 .36$

Received: 6 September 2016 / Accepted: 4 October 2016 / Published: 10 November 2016

In this work, we studied the corrosion behavior of the reinforcing steel in salt lake water with various immersion time by the measurement of electrochemical impedance spectroscopy (EIS). We found that the polarization resistance and capacitive loop decreased when increasing the immersion time. Moreover, the corrosion process was also influenced by the temperature of the salt lake water. The generation, growth and break of the passivation film on the embedded steel was investigated according to the dependence of the temperature and immersion time.

Keywords: Concrete; Corrosion; Electrochemical impedance spectroscopy; Salt lake

\section{$\underline{\text { FULL TEXT }}$}

(C) 2016 The Authors. Published by ESG (www.electrochemsci.org). This article is an open access article distributed under the terms and conditions of the Creative Commons Attribution license (http://creativecommons.org/licenses/by/4.0/). 